\section{Eugenia uniflora Dentifrice for Treating Gingivitis in Children: Antibacterial Assay and Randomized Clinical Trial}

Vanessa de Carvalho Jovito', Irlan Almeida Freires², Danilo Augusto de Holanda Ferreira1, Marçal de Queiroz Paulo ${ }^{3}$, Ricardo Dias de Castro 4
${ }^{1}$ Center for Health Sciences, UFPB - Universidade Federal da Paraíba, João Pessoa, PB, Brazil ${ }^{2}$ Department of Physiological Sciences, Piracicaba Dental School, UNICAMP - Universidade Estadual de Campinas, Piracicaba, SP, Brazil ${ }^{3}$ Department of Chemistry, Center for Exact Sciences and Nature, UFPB - Universidade Federal da Paraíba, João Pessoa, PB, Brazil ${ }^{4}$ Department of Speech Therapy, UFPB - Universidade Federal da Paraíba, João Pessoa, PB, Brazil

Correspondence: Ricardo Dias de Castro, Rua Barão Adalto Lucio, 24, 58051-900 João Pessoa, PB, Brasil. Tel: +55-83-3216-7877. e-mail: ricardodiasdecastro@yahoo.com.br

Key Words: gingivitis, dentifrice, biofilm, Eugenia uniflora, Surinam cherry.

\section{Introduction}

Gingivitis is the most prevalent condition affecting the periodontium in pediatric patients $(1,2)$. This highly prevalent disease among children and young adults results from the interplay between bacterial virulence factors and the host's limited defense capacity (3).

Even developed countries have shown high prevalence and incidence rates of periodontal disease (4). This epidemiological status quo requires the adoption of measures to address this public health issue by educational, preventive and therapeutic actions. This background encourages the use of alternative therapies for oral health care, particularly in communities with limited access to health services (4). Natural products have shown to be potential therapeutic resources for treating oral diseases, especially of infectious nature, such as dental caries (5) and candidiasis (6), and of inflammatory origin, such as gingivitis (7).

Based on its common medicinal use, this research group and others have explored the pharmacological potential of Eugenia uniflora L. extracts, which is also known as Surinam cherry. Extracts from the leaves, stems and fruits were recognized for their promising antimicrobial and anti-inflammatory activities (8-10). Furthermore, this plant can be found in several countries because it adapts easily to different weather and soil conditions (9).

Previous studies have investigated the toxicity potential of E. uniflora L. extract and confirmed that it is safe for clinical use (11). Moreover, the ripe fruit (used in the present study) is edible and there are no reports of adverse effects related to its use.

Therefore, the wide distribution of E. uniflora in South America, the proven biological properties and presence of bioactive chemical compounds (mainly sesquiterpenes) (810), the negligible toxicity of its fruits (11), and finally the potential development of an effective, low-cost dentifrice for economically disadvantaged communities - at least comparable to the ones available in the market - have encouraged us to develop an E. uniflora experimental dentifrice. Herein, this study investigated the in vitro antibacterial activity and short-term clinical efficacy of this dentifrice containing E. uniflora L. extract versus a triclosan-based comparator in treating gingivitis and biofilm accumulation in children. 


\section{Material and Methods}

The present study was conducted in two stages: (i) in vitro evaluation of the antibacterial activity of $E$. uniflora L. dentifrice against oral pathogens; and (ii) phase II clinical trial of the experimental dentifrice in subjects with gingivitis.

The hydroalcoholic extract of E. uniflora ripe fruit and the pharmaceutical formulation of the dentifrice were performed at the Natural Products Chemistry Laboratory of the Federal University of Paraiba. Each $10 \mathrm{~mL}$ of E. uniflora L. dentifrice comprises the following components as described by Jovito et al. (8): hydroalcoholic extract of the ripe fruit of E. uniflora L. (3.0\%), preservatives (parabenes, $0.02 \mathrm{~g}$ ), and dentifrice base (silicon dioxide, sodium lauryl sulfate, white dye, aromatic compounds, sodium saccharin and Gangrez sodium salt; q.s.p.).

\section{In Vitro Phase: Evaluation of Antimicrobial Activity}

The in vitro minimum inhibitory concentration (MIC) of the dentifrices was determined by the agar diffusion technique described by Bauer (12). Serial dilutions of the Briefly, $3 \mathrm{~g}$ of dentifrice was dissolved in $10 \mathrm{~mL}$ of sterile distilled water, yielding a solution that was subsequently centrifuged at 5,000 rpm for $10 \mathrm{~min}$ to precipitate the solid particles. After centrifugation, the supernatant obtained from each dentifrice was used for the antibacterial assay. Streptococcus mutans (ATCC 25175), Streptococcus oralis (ATCC 10557), and Lactobacillus casei (ATCC 7469) strains were tested in the present study. The inoculum was adjusted according to the 0.5 tube of McFarland standard, which corresponds to approximately $1.5 \times 10^{8} \mathrm{CFU} / \mathrm{mL}$. The bacterial suspensions were seeded onto agar plates and well-shaped 6-mm perforations were made in the solid culture medium afterwards. Samples of $50 \mu \mathrm{L}$ of dentifrice supernatant at different concentrations were inserted in the wells. The plates were incubated at $37{ }^{\circ} \mathrm{C}$ and $5 \% \mathrm{CO}_{2}$ for $24 \mathrm{~h}$. The MIC was defined as the lowest concentration of the dentifrice that inhibited visible bacterial growth.

\section{Phase II Clinical Trial Study Design}

After the antibacterial activity of the experimental dentifrice was confirmed in vitro, was carried out the phase II: a randomized, controlled, double-blind clinical trial comparing the experimental and control dentifrices. The study had a parallel design and investigated the short-term clinical efficacy of Surinam cherry dentifrice against gingivitis and biofilm accumulation). The CONSORT guidelines were followed to design this investigation.

\section{Study Participants}

Eligibility criteria were used to select a homogenous sample to participate in the clinical trial. As inclusion criteria, were selected children of both sexes aged 10 to 12 years, with presence of at least 15 teeth, showing biofilminduced gingivitis and whose participation was consented by their parents/legal guardians. Excluded subjects were those with systemic conditions that could interfere with periodontal health; wearers of fixed/removable orthodontic appliances; mouthrinse users or subjected to topical fluoride application in the previous three months; and undergoing treatment with antimicrobials or anti-inflammatory drugs. All subjects were recruited at a public school in the city of João Pessoa, PB, Brazil, where their examinations were carried out and one of the three daily tooth-brushings was supervised (directly).

The sample size was estimated using Fleming's singlestage procedure for phase II trials (13). With regard to the primary outcome, a response proportion of at least 50\% was defined as being clinically significant. The type I error was set as 0.05 , and the type II error was set at 0.1 . Based on these values, a sample size of 20 individuals per trial arm would provide $90 \%$ power $(1-\beta)$ to detect any clinically relevant treatment difference of $50 \%$ or greater compared to baseline. Taking into consideration an attrition rate of approximately $20 \%$, the final sample size per trial arm comprised 25 individuals.

\section{Randomization}

After meeting the eligibility criteria, subjects were number-coded and their allocation into the experimental or control group was determined by drawing lots with replacement. Allocation data were concealed by a single researcher, who did not examine the subjects, in a sealed envelope during the whole performance of the study.

\section{Blinding}

The experimental and control dentifrices were kept in similar containers, and had the same color (white), taste (mint) and smell (mint). Thus, neither the participants nor the examiners were aware of the allocated interventions, characterizing the study as double-blinded.

\section{Control}

A commercially available dentifrice containing 1500 ppm fluoride and $0.3 \%$ triclosan (Colgate Total $12^{\circledR}$, Colgate-Palmolive Company) was used as control due to its known effects against gingivitis and plaque formation. 
Subjects allocated to the control group followed the same procedures as those of the experimental group.

\section{Intra-Examiner Agreement}

The examination of subjects concerning the study outcome indices was performed by a single examiner who was adequately calibrated with a Kappa statistic of 0.8, which is considered to be satisfactory agreement, according to Landis \&t Koch (14).

\section{Intervention Protocol}

The experimental group comprised 25 subjects who used the dentifrice with E. uniflora L. ripe fruit hydroalcoholic extract, three times per day, for seven consecutive days. The control group comprised 25 subjects who used the control dentifrice (fluoride, $1500 \mathrm{ppm}$ and triclosan, 0.3\%), three times per day, for seven consecutive days. The participants (and their parents) were instructed as to the number of three daily brushings and one of them was supervised at school by the researchers. They were also instructed concerning the pea-sized amount of dentifrice to be used. An active personal and telephonic contact was established with the parents in order to assure protocol compliance.

\section{Primary and Secondary Outcomes of Interest}

Clinical examinations were performed at baseline and after seven days of dentifrice use. The examination data were recorded in a specific clinical chart. The diagnosis of gingivitis (primary outcome) was established by bleeding on probing using the Gingival Bleeding Index (GBI) proposed by Ainamo and Bay (15). The accumulation of biofilm (secondary outcome) was assessed with the Simplified Oral

Table 1. Evaluation of the Minimum Inhibitory Concentration (MIC) of the experimental and control dentifrices against Streptococcus mutans ATCC 25175, Streptococcus oralis ATCC 10557 and Lactobacillus casei ATCC 7469. The zones of inhibition are expressed in millimeters (mm)

\begin{tabular}{|c|c|c|c|c|c|c|}
\hline \multirow{3}{*}{$\begin{array}{l}\text { Sample } \\
\text { concentration }\end{array}$} & \multicolumn{6}{|c|}{ Inhibition zone $(\mathrm{mm})$} \\
\hline & \multicolumn{2}{|c|}{ S. mutans } & \multicolumn{2}{|c|}{ S. oralis } & \multicolumn{2}{|c|}{ L. casei } \\
\hline & SC & Ctrl & SC & Ctrl & SC & Ctrl \\
\hline $0.3 \mathrm{~g} / \mathrm{mL}$ & 14.0 & 18.0 & 23 & 30 & 26 & 20 \\
\hline $0.15 \mathrm{~g} / \mathrm{mL}$ & 12.0 & 14.0 & 19 & 29 & 25 & 19 \\
\hline $0.075 \mathrm{~g} / \mathrm{mL}$ & 11.0 & 12.0 & 15 & 25 & 19 & 15 \\
\hline $0.0375 \mathrm{~g} / \mathrm{mL}$ & 10.0 & 11.0 & 15 & 24 & 18 & 13 \\
\hline $0.01875 \mathrm{~g} / \mathrm{mL}$ & 7.0 & 10.0 & 15 & 15 & 18 & 12 \\
\hline $0.009375 \mathrm{~g} / \mathrm{mL}$ & 7.0 & 9.5 & 14 & 14 & 18 & 12 \\
\hline $0.005 \mathrm{~g} / \mathrm{mL}$ & 0.0 & 9.0 & 14 & 13 & 18 & 11 \\
\hline
\end{tabular}

Note: SC, Surinam cherry experimental dentifrice; Ctrl, control dentifrice (Colgate Total $12^{\circ}$ ).
Hygiene Index (OHI-S) described by Greene and Vermilion (16). Prior to the study, all subjects were instructed on correct tooth brushing techniques and received a kit that contained a toothbrush and one of the dentifrices (without the identification of its contents).

\section{Ethical and Regulatory Aspects}

The present study was approved by the Ethics Research Committee of the João Pessoa University Center (Centro Universitário de João Pessoa, UNIPÊ), João Pessoa, $\mathrm{PB}$, Brazil. The parents/legal guardians of each of the participating children signed a detailed informed consent form to authorize their participation. The study followed the guidelines of the 466/12 Resolution of the Brazilian National Health Council, which encompasses the Helsinki Declaration. Moreover, the clinical trial was registered at ClinicalTrials.gov under protocol NCT02648139.

\section{Statistical Analysis}

The data were analyzed on GraphPad Prism version 5.0 statistical software (GraphPad Software, Inc., La Jolla, CA, USA). Intra- and intergroup comparisons at baseline and post-interventions were performed using paired $t$ and unpaired t tests (for GBI data) and Wilcoxon signedrank test and Mann-Whitney test (for S-OHI data), with a significance level of $5 \%$.

\section{Results}

Table 1 shows the results of the in vitro antibacterial activity of the dentifrices against oral microorganisms. The MIC of both the experimental and control dentifrices was $5 \mathrm{mg} / \mathrm{mL}$ against all bacterial strains, except for E. uniflora dentifrice against S. mutans, which was $9.3 \mathrm{mg} / \mathrm{mL}$.

All participants completed the phase II clinical trial, therefore with no loss of follow-up. Regarding the experimental and control arms, $32 \%$ and $52 \%$ of the sample were males, respectively, and $68 \%$ and $48 \%$ females. The median number of teeth was 24 in the experimental group and 26 in the control group. The baseline levels of gingival inflammation and biofilm accumulation were not different between groups ( $p>0.05$ ), thus characterizing a clinically homogenous sample.

As seen in Table 2, the study findings demonstrated that both the experimental and control dentifrices significantly reduced the levels of gingival bleeding as compared to baseline $(p<0.0001)$. The means of differences between baseline and post-intervention data showed no significant difference in the effectiveness of Surinam cherry dentifrice and the triclosan-based comparator $(p=0.178)$, although a small size effect was observed. Table 3 shows the effect of the dentifrices in reducing biofilm accumulation after seven days of dentifrice use. It may be clearly seen that 
only the triclosan-based dentifrice was able to reduce the accumulation of dental biofilm during this period $(p=0.0039)$ (Table 3). No adverse effects were reported or clinically identified during examinations.

\section{Discussion}

In dentistry, there has been an increase in the use of medicinal plants and molecules extracted from natural products for the preparation of products with pharmacological properties. Nevertheless, many gaps remain in the experimental design and analytical methodology used in most studies, which makes it difficult to translate in vitro findings into efficient and safe clinical use $(5,6)$. The present study aimed to contribute to the development of an effective and low cost formulation that improves oral health by promoting the ecological and biochemical balance of the oral cavity.

The Brazilian Ministry of Health recently released a list of plants with the aim of guiding research to evaluate whether they may be used by the public health system. $E$. uniflora L. (Surinam cherry), which has antimicrobial activity against bacteria present in oral biofilm that cause caries and periodontal diseases, was one of the listed species $(8,9)$.

$\vec{\sigma}$ These data support the findings of this study, in which the experimental dentifrice exhibited in vitro antibacterial activity against streptococci and lactobacilli. As expected, the conducted study also confirmed the antimicrobial potential of the control dentifrice containing triclosan, which is a chemical agent recognized in literature as having antimicrobial properties (17).

The choice to include S. mutans, S. oralis, and L. casei strains was because they are part of the normal oral biofilm microbiota and participate in either the initial (S. oralis and S. mutans) or advanced (L. casei) colonization process of the microbial community (18-20). Because gingival inflammation results from the initial colonization of the dental surface by these microorganisms, it is necessary to disrupt microbial colonization to avoid microbial growth and establishment of periodontal pathogenic bacteria responsible for advanced periodontal disease $(20,21)$.

The observed reduction in gingival bleeding produced by the dentifrice containing the hydroalcoholic extract from E. uniflora ripe fruit suggests that the product has the potential to prevent and/or treat gingivitis. In a previous study conducted by this research group, this dentifrice also reduced gingivitis in a sample of 40 undergraduate students between 21 and 24 years of age, following 22 consecutive days of dentifrice use (8).

There was no significant reduction in OHI-S postintervention scores, which measure tooth surface biofilm accumulation, as compared to baseline in the experimental group. This finding may be due to the following reasons:

Table 2. Mean Gingival Bleeding Index (GBI) values $( \pm \mathrm{SD}$ ) for the experimental (Surinam cherry dentifrice) and control (Triclosan-based dentifrice) groups at baseline and after 7-day treatment. 95\% confidence interval values are expressed in brackets

\begin{tabular}{|c|c|c|c|c|c|c|}
\hline $\begin{array}{l}\text { Gingival } \\
\text { Bleeding Index }\end{array}$ & $\begin{array}{l}\text { Baseline } \\
\text { (B) }\end{array}$ & $\begin{array}{l}\text { Post-intervention } \\
\text { (PI) }\end{array}$ & $\begin{array}{l}\text { Mean of differences } \\
\text { between (B) and (PI) }\end{array}$ & Effect size* $^{*}$ & $\begin{array}{l}\text { Intra-group } \\
\text { difference }^{+}\end{array}$ & $\begin{array}{l}\text { Inter-group } \\
\text { difference }^{\#}\end{array}$ \\
\hline $\begin{array}{l}\text { Surinam cherry } \\
\text { dentifrice }\end{array}$ & $\begin{array}{c}3.45 \pm 1.80 \\
{[2.704 \text { to } 4.192]}\end{array}$ & $\begin{array}{c}1.13 \pm 1.48 \\
{[0.522 \text { to } 1.749]}\end{array}$ & $\begin{array}{c}2.32 \pm 1.11 \\
{[1.856 \text { to } 2.769]}\end{array}$ & \multirow{2}{*}{$\begin{array}{c}0.396 \\
{[-0.163 \text { to } 0.956]}\end{array}$} & $P<0.0001$ & \multirow{2}{*}{$P=0.178$} \\
\hline $\begin{array}{l}\text { Triclosan-based } \\
\text { dentifrice }\end{array}$ & $\begin{array}{c}2.974 \pm 1.15 \\
{[2.499 \text { to } 3.450]}\end{array}$ & $\begin{array}{c}1.10 \pm 0.91 \\
{[0.724 \text { to } 1.479]}\end{array}$ & $\begin{array}{c}1.87 \pm 1.16 \\
{[1.393 \text { to } 2.354]}\end{array}$ & & $P<0.0001$ & \\
\hline
\end{tabular}

*The effect size for GBI was calculated based on the mean of differences between (B) and (PI) and standard deviation. tIntra-group comparisons before and after intervention (paired-t test, $\mathrm{p} \leq 0.05$ ). \#Comparisons of the mean of differences (4th column) between the groups Surinam cherry vs. Triclosan-based dentifrice (unpaired-t test, $\mathrm{p} \leq 0.05$ ).

Table 3. Median Simplified Oral Hygiene Index (S-OHI) values (plus inter-quartile range) for the experimental (Surinam cherry dentifrice) and control (triclosan-based dentifrice) groups at baseline and after 7-day treatment. Minimum and maximum interquartile range is presented in parenthesis and 95\% confidence interval values are expressed in brackets

\begin{tabular}{|c|c|c|c|c|c|c|}
\hline $\begin{array}{l}\text { Simplified Oral } \\
\text { Hygiene Index }\end{array}$ & $\begin{array}{l}\text { Baseline } \\
\text { (B) }\end{array}$ & $\begin{array}{l}\text { Post-intervention } \\
\text { (PI) }\end{array}$ & $\begin{array}{l}\text { Sum of ranks } \\
\text { of differences } \\
\text { between (B) } \\
\text { and (PI) }\end{array}$ & Effect size $^{*}$ & $\begin{array}{l}\text { Intra-group } \\
\text { difference }^{\dagger}\end{array}$ & $\begin{array}{l}\text { Inter-group } \\
\text { difference }^{\#}\end{array}$ \\
\hline $\begin{array}{l}\text { Surinam cherry } \\
\text { dentifrice }\end{array}$ & $\begin{array}{c}1.16(0.75) \\
{[1.075 \text { to } 1.607]}\end{array}$ & $\begin{array}{c}1.16(0.33) \\
{[0.982 \text { to } 1.411]}\end{array}$ & 714 & \multirow{2}{*}{$\begin{array}{c}0.386 \\
{[-0.173 \text { to } 0.945]}\end{array}$} & $P=0.1006$ & \multirow{2}{*}{$P=0.139$} \\
\hline $\begin{array}{l}\text { Triclosan-based } \\
\text { dentifrice }\end{array}$ & $\begin{array}{c}1.33(0.34) \\
{[1.206 \text { to } 1.513]}\end{array}$ & $\begin{array}{c}1.16(0.58) \\
{[0.922 \text { to } 1.190]}\end{array}$ & 561 & & $P=0.0039$ & \\
\hline
\end{tabular}

${ }^{¥}$ Mann-Whitney U: 236. "The effect size for S-OHI was calculated based on median values and interquartile range. ${ }^{\star}$ Intra-group comparisons before and after intervention (Wilcoxon signed-rank test, $\mathrm{p} \leq 0.05)$; " Comparisons of the sum of ranks of differences $\left(4^{\text {th }}\right.$ column) between the groups Surinam cherry vs. triclosan-based dentifrice (Mann-Whitney test, $\mathrm{p} \leq 0.05$ ). 
low abrasive potential of the dentifrice, resulting in poor mechanical removal of biofilm; or a low in vivo concentration, which may have not been enough to produce the same effects observed in vitro, due to salivary clearance, substantivity and other factors inherent to the human body. In contrast, the control dentifrice was efficient in reducing biofilm accumulation, which corroborates previous studies that evaluated the potential of triclosan-based dentifrices $(17,22-24)$.

The ripe fruit of $E$. uniflora contains flavonoids, which are chemical markers of anti-inflammatory activity. The activity of the experimental dentifrice active component may be directly associated with certain pathways of the inflammatory process because there was a reduction in gingival bleeding but not in biofilm accumulation (25).

Similarly, Soares (10) conducted an in vivo evaluation of a mouthwash containing the hydroalcoholic extract of E. uniflora ripe fruit in individuals wearing orthodontic braces. The author observed a statistically significant reduction in gingival bleeding based on the GBI $(p<0.05)$ and in bacterial counts for $S$. mutans $(p<0.01)$, but not in biofilm accumulation based on the $\mathrm{OHI}-\mathrm{S}(\mathrm{p}>0.05)$ before (baseline) and after (post-intervention, 15 days) dentifrice use. These findings could also be explained by the antiinflammatory activities of E. uniflora.

The results of the present study suggest the need for additional clinical trials focusing on the anti-inflammatory potential of E. uniflora. Although no adverse effects were reported by research subjects, it is important to investigate the long-term clinical and toxicological effects of the experimental dentifrice.

Furthermore, the need for pharmaceutical technological support should be stressed for formulating a dentifrice with satisfactory physical and chemical properties. In particular, certain aspects of the dentifrice: color, taste and abrasiveness require improvement.

This study demonstrated that the dentifrice containing the hydroalcoholic ripe fruit extract of E. uniflora $\mathrm{L}$. (Surinam cherry) showed anti-gingivitis properties in children aged 10 to 12 years. E. uniflora dentifrice may be a potentially efficient and safe product to be used alternatively in preventive dental practice.

\section{Resumo}

Crianças em idade escolar apresentam, com frequência, alto risco para o desenvolvimento de doenças biofilme-dependentes, incluindo cárie e doenças periodontais. Este estudo investigou a eficácia clínica de um dentifrício contendo o extrato de Eugenia uniflora Linn. (pitanga) comparado a um dentifrício com triclosan no combate à gengivite em crianças de 10 a 12 anos. Foi avaliado o potencial antibacteriano in vitro do dentifrício sobre microorganismos da cavidade oral (S. mutans $S$. oralis and $L$. casei) e realizado um estudo clínico fase II incluindo 50 sujeitos, com sinais clínicos de gengivite, divididos aleatoriamente em dois grupos: Experimental - 25 sujeitos usaram o dentifrício contendo extrato de pitanga; e Controle - 25 sujeitos que usaram um dentifrício fluoretado contendo triclosan (Colgate Total $12^{\circledR}$ ). Na baseline e após sete dias consecutivos de escovação, foi realizado o exame clínico para diagnóstico de gengivite (desfecho primário) e acúmulo de biofilme (desfecho secundário), utilizando o Índice de Sangramento Gengival (ISG) e Índice de Higiene Oral Simplificado (IHO-S). Os dados foram analisados utilizando o teste t pareado e não pareado (ISG) e teste de Wilcoxon e Mann-Whitney (IHO-S), com nivel de significância de $p \leq 0,05$. Observouse uma efetiva atividade antibacteriana do dentifricio experimental. No estudo clínico, observou-se redução de sangramento gengival em ambos os grupos experimental e controle $(p<0,0001)$, não havendo diferença entre eles $(p 0,178)$, embora com uma pequena magnitude de efeito. Apenas o grupo controle reduziu significantemente o acúmulo de biofilme $(p=0,0039)$. Concluiu-se que o dentifrício experimental de E. uniflora mostrou-se eficaz na redução de gengivite em crianças de 10 a 12 anos. Assim, este dentifrício apresenta potencial para ser utilizado de forma eficaz e segura em odontologia preventiva.

\section{References}

1. Rosema NA, Helderman WHVP, Van Der Weijden GA. Gingivitis and plaque scores of 8- to 11-year-old Burmese children following participation in a 2-year school-based toothbrushing programme. Int J Dent Hyg 2012;10:163-168.

2. Hashim R, Williams $S$, Thomson WM. Oral hygiene and dental caries in 5- to 6-year-old children in Ajman, United Arab Emirates. Int J Dent Hyg 2013;11:208-215.

3. Gafan GP, Lucas VS, Roberts GJ, Petrie A, Wilson M, Spratt DA. Prevalence of periodontal pathogens in dental plaque of children. J Clin Microbiol 2004;42:4141-4146.

4. Petersen PE, Ogawa $H$. The global burden of periodontal disease: towards integration with chronic disease prevention and control. Periodontology 2000 2012:60:15-39.

5. Freires IA, Denny C, Benso B, Alencar SM, Rosalen PL. Antibacterial activity of essential oils and their isolated constituents against cariogenic bacteria: a systematic review. Molecules 2015;20:73297358.

6. Ferreira GLS, Pérez ALAL, Rocha IM, Pinheiro MA, Castro RD, Carlo HL, et al.. Does scientific evidence for the use of natural products in the treatment of oral candidiasis exist? A systematic review. Evid Based Complem Alternat Med 2015;2015:147804.

7. Freires IA, Alves LA, Ferreira GLS, Jovito VC, Castro RD, Cavalcanti AL. A randomized clinical trial of Schinus terebinthifolius mouthwash to treat biofilm-induced gingivitis. Evid Based Complem Alternat Med 2013:2013:873907..

8. ovito VC, Almeida LFD, Ferreira DAH, Moura D, Paulo MQ, Padilha WWN. In vivo evaluation of a dentifrice containing Eugenia uniflora L. extract on oral health indicators. Pesq Bras Odontoped Clin Integr 2009:9:8186.

9. Soares JD, Walker J, Pignitter M, Walker JM, Imboeck JM, EhrnhoeferRessler MM, et al.. Pitanga (Eugenia uniflora L.) fruit juice and two major constituents thereof exhibit anti-inflammatory properties in human gingival and oral gum epithelial cells. Food Funct 2014;5:29812988.

10. Victoria FN, Lenardão EJ, Savegnago L, Perin G, Jacob RG, Alves D, et al.. Essential oil of the leaves of Eugenia uniflora L.: Antioxidant and antimicrobial properties. Food Chem Toxicol 2012;50:2668-2674.

11. Schmeda-Hirschmann G, Theoduloz C, Franco L, Ferro E, de Arias AR. Preliminary pharmacological studies on Eugenia uniflora leaves: xanthine oxidase inhibitory activity. J. Ethnopharmacol 1987;21:183186.

12. Bauer AW, Kirbi WMM, Sherris JC, Turck M. Antibiotic susceptibility testing by a standardized single disk method. Am J Clinical Pathol 1969;45:493-496.

13. Fleming, TR. One-sample multiple testing procedure for Phase II clinical trials. Biometrics 1982;38:143-151.

14. Landis JR, Koch GG. The measurement of observer agreement for categorical data. Biometrics 1977;33:159-174.

15. Ainamo J, Bay I. Problems and proposals for recording gingivitis and 
plaque. Int. Dent J 1975;25:229-235

16. Greene JC, Vermillion JR. The simplified oral hygiene index. J Amer Dent Ass 1964;68:7-13.

17. Rossi $A D$, Ferreira $D C A$, Silva $R A B$, Queiroz AM, Silva $L A B$, Nelson-Filho P. Antimicrobial activity of toothpastes containing natural extracts, chlorhexidine or triclosan. Braz Dent J 2014;25:186-190.

18. Gross EL, Beall CJ, Kutsch SR, Firestone ND, Leys EJ, Griffen AL. Beyond Streptococcus mutans: dental caries onset linked to multiple species by 16S rRNA community analysis. PLoS ONE 2012;7:e47722.

19. Smith SI, Aweh AJ, Coker AO, Savage KO, Abosede DA, Oyedeji KS. Lactobacilli in human dental caries and saliva. Microbios 2001;105:7785.

20. Marsh, PD. Microbiology of dental plaque biofilms and their role in oral health and caries. Dent. Clin. North Am. 2010;54:441-454.

21. Haas AN, Reis A, Lemos CA, Pannuti CM, Escobar E, Almeida ER et al.. Daily biofilm control and oral health: an epidemiological challenge consensus - Brazilian advisory panel in oral health. Braz J Periodontol 2012;22:40-46.

22. Davies RM, Ellwood RP, Davies GM. The effectiveness of a toothpaste containing triclosan and polyvinyl-methyl ether maleic acid copolymer in improving plaque control and gingival health. A systematic review. J Clin Periodontol 2004;31:1029-1033.
23. Wainwright J, Sheiham A. An analysis of methods of tooth brushing recommended by dental associations, toothpaste and toothbrush companies and in dental texts. Brit Dent J 2014;217:E5.

24. Diaz MAN, Carvalho IO, Gaspar D. Herbal Dentifrices for Children, Emerging Trends in Oral Health Sciences and Dentistry. 2015. Available from: http://www.intechopen.com/books/emerging-trends-in-oralhealth-sciences-and-dentistry/herbal-dentifrices-for-children. Latest access August 3, 2016.

25. Bagetti, M. et al.. Physicochemical characterization and antioxidant capacity of pitanga fruits (Eugenia uniflora L.). Ciênc. Tecnol. Aliment. 2011;31:147-154.

Received January 6, 2016 Accepted May 27, 2016 